\title{
PENGARUH DEWAN PENGAWAS SYARIAH, PROFITABILITAS DAN LEVERAGE TERHADAP PENGUNGKAPAN ISLAMIC SOCIAL REPORTING (ISR) \\ (Studi Pada Bank Umum Syariah di Indonesia Periode 2012-2016)
}

\author{
Siti Sara Rostiani ${ }^{1}$, Tuntun A. Sukanta ${ }^{2}$ \\ 1. STIE STAN Indonesia Mandiri \\ Jl. Jakarta No. 79 Bandung \\ kontaksitisararostiani@gmail.com \\ 2. STIE STAN Indonesia Mandiri \\ Jl. Jakarta No. 79 Bandung
}

\begin{abstract}
The purpose of this research is to find out the influence of sharia supervisory board, profitability, and leverage toward the disclosure of Islamic Social Reporting (ISR) at Sharia Commercial Bank in Indonesia during 2012-2016 and test it. Purposing sampling is the technique that been used in this research with the samples 9 Sharia Commercial Bank during 5 years observation respectively with the result obtained 45 samples. The analysis technique used in this research was multiple regressions. The analysis result shows that syaria supervisory board has a positive significant influenced toward the disclosure of Islamic Social Reporting (ISR). While profitability and leverage has no significant influenced toward the disclosure of Islamic Social Reporting (ISR).
\end{abstract}

Keywords : $\quad$ Sharia Supervisory Board, Profitability, Leverage, Disclosure of Islamic Social Reporting (ISR)

\section{PENDAHULUAN}

Perkembangan praktik tanggung jawab sosial, atau disebut dengan Corporate Social Responsibility (CSR) kian menjadi sorotan penting dalam beberapa dekade terakhir, karena konsep CSR merupakan inti dari etika bisnis bagi setiap perusahaan (Widiawati dan Raharja, 2012). Hal ini terlihat dari semakin maraknya unit-unit bisnis yang melaporkan praktik CSR dalam laporan keuangan tahunan maupun press release lainnya (Fitria dan Hartanti, 2010).

Mahdalena (2017) memaparkan bahwa perkembangan praktik dan pengungkapan CSR di Indonesia juga mendapat dukungan dari pemerintah. Hal itu terlihat dengan diterbitkannya Undang-Undang No. 40 Tahun 2007 yang menyebutkan bahwa laporan tahunan harus memuat beberapa informasi, salah satunya adalah laporan pelaksanaan Tanggung Jawab Sosial dan Lingkungan.

(20) Ulama


Secara umum praktik CSR lebih banyak dilakukan oleh perusahaan tambang maupun manufaktur, namun seiring dengan adanya trend global akan praktik CSR, saat ini industri perbankan juga telah menyebutkan aspek pertanggungjawaban sosial dalam laporan tahunan walaupun dalam bentuk yang relatif sederhana (Setiawan et al., 2016). Namun pengungkapan tanggung jawab sosial ini tidak hanya berkembang pada perbankan konvensional, tetapi juga pada perbankan yang berbasis syariah (Maharani dan Yuliyanto, 2016). Sebagai suatu perbankan yang berbasis syariah, maka perlu adanya kerangka khusus untuk pelaporan tanggung jawab sosial yang sesuai dengan prinsip Islam (Haniffa, 2002).

Haniffa (2002) menyatakan bahwa selama ini pengukuran CSR Disclosure yang terdapat pada perbankan syariah masih mengacu pada Global Reporting Initiative Index (GRI). Pedoman baku terkait entitas syariah pada pengungkapan Corporate Social Responsibility (CSR) masih belum ada (Sintia, 2016). Sehingga peneliti-peneliti ekonomi syariah saat ini banyak yang menggunakan Indeks Islamic Social Reporting (ISR) untuk mengukur CSR pada institusi keuangan syariah. Karena Indeks ISR ini sesuai dengan prinsip syariah. Indeks ISR berisi item-item standar CSR yang ditetapkan oleh AAOIFI (Accounting and Auditing Organization for Islamic Financial Institution). Menurut Fitria dan Hartanti (2010) indeks ISR diyakini dapat menjadi tolak ukur dalam hal standar pengungkapan CSR yang sesuai dengan perspektif Islam.

Berdasarkan penelitian yang dilakukan International Institute of Islamic Thought (IIIT) tahun 1996 terindikasi bahwa bank syariah tidak sepenuhnya menjalankan peran sosialnya sesuai dengan tuntutan Islam. Sebanyak 32 bank syariah didunia lebih memprioritaskan tujuan ekonomi lebih diutamakan dibandingkan kriteria sosial ketika mengevaluasi peluang investasi (Maali et al., 2003). Menurut Maali et al. (2003) bank syariah dinilai kurang dalam memberikan dukungan terhadap Usaha Kecil dan Menengah (UKM) untuk meningkatkan level ekonomi pengusaha kelas menengah. Anggarwal dan Youssef (2000) dalam Farook dan Lanis (2005) berpendapat bahwa insentif ekonomis lebih membentuk struktur perbankan syariah daripada norma religius yang seharusnya menjadi pijakan.

Praktik CSR sering kali tidak memasukkan etika bisnis Islam dalam bingkai ekonomi Islam (Edi Soeharto, 2010 dalam Rusdianto, 2014). Penelitian yang dilakukan oleh Maali et al. (2003) yang menggunakan sampel 29 bank syariah di negara-negara muslim. Hasilnya menunjukkan bahwa hanya sebelas bank syariah (38\%) yang mengungkapkan pertanggungjawaban sosialnya sesuai dengan standar yang ditetapkan oleh AAOIFI. Hasil penelitian ini mengindikasikan bahwa $62 \%$ bank syariah tidak mengungkapan pertanggungjawaban sosialnya sebagaimana yang diharapkan.

Kasus lain yang berhubungan dengan Islamic Social Reporting (ISR) adalah kasus yang terjadi pada Bank Syariah Mandiri dan Bank Muamalat Indonesia. Penelitian yang dilakukan oleh Purwitasari (2011) dalam Ningrum et al. (2013) pada Bank Syariah Mandiri dan Bank Mualamat Indonesia menunjukan bahwa tindakan pelaporan tanggung jawab sosial oleh BSM dan BMI masih dipengaruhi oleh kepentingan mereka masing-masing. Kepentingan ini terutama dipengaruhi oleh money dan power. 
Beberapa penelitian terdahulu meneliti faktor-faktor yang mempengaruhi pengungkapan Islamic Social Reporting (ISR). Roziani dan Sofie (2010) menyatakan bahwa faktor yang mempengaruhi pengungkapan ISR adalah rasio likuiditas. Widiawati dan Raharja (2012) menyatakan bahwa faktor yang mempengaruhi pengungkapan ISR adalah profitabilitas, tipe industri dan jenis bank. Khoirudin (2013) menyatakan bahwa faktor yang mempengaruhi pengungkapan ISR adalah ukuran dewan komisaris. Ningrum et al. (2013) menyatakan bahwa faktor yang mempengaruhi pengungkapan ISR adalah kepemilikan institusional dan ukuran dewan pengawas syariah. Astuti (2014) menyatakan bahwa faktor yang mempengaruhi pengungkapan ISR adalah ukuran perusahaan (size) dan leverage. Putri dan Yuyetta (2014) menyatakan bahwa faktor yang mempengaruhi pengungkapan ISR adalah surat berharga syariah. Khasanah dan Yuliyanto (2015) menyatakan bahwa faktor yang mempengaruhi pengungkapan ISR adalah Investment Account Holders dan kepatuhan syariah. Jannah dan Asrori (2016) menyatakan bahwa faktor yang mempengaruhi pengungkapan ISR adalah jenis produk. Novrizal dan Fitri (2016) menyatakan bahwa faktor yang mempengaruhi pengungkapan ISR adalah kinerja lingkungan hidup. Yuliani (2016) menyatakan bahwa faktor yang mempengaruhi pengungkapan ISR adalah jumlah komite remunerasi dan nominasi. Setiawan et al. (2016) menyatakan bahwa faktor yang mempengaruhi pengungkapan ISR adalah ukuran bank.

Berdasarkan penjelasan mengenai faktor-faktor yang mempengaruhi pengungkapan Islamic Social Reporting (ISR), maka penulis tertarik untuk melakukan penelitian dengan mengangkat tiga variabel yaitu dewan pengawas syariah, profitabilitas, dan leverage. Alasan penulis mengangkat tiga variabel tersebut karena dewan pengawas syariah mempunyai peran dalam pengungkapan ISR pada perbankan syariah. Dewan pengawas syariah mempunyai wewenang mengawasi kepatuhan perusahaan terhadap prinsip syariah. Oleh karena itu, semakin banyak dewan pengawas syariah maka semakin efektif pula pengawasan terhadap pengungkapan ISR berdasarkan prinsip syariah (Mahdalena, 2017).

Bank dalam posisi menguntungkan akan cenderung melakukan pengungkapan informasi yang lebih luas dalam laporan tahunannya. Bank dengan profitabilitas yang tinggi membuat manajemen memiliki kebebasan dan kemudahan untuk menyatakan program tanggung jawab sosialnya yang luas kepada para stakeholders (Ramadhani, 2016). Othman et al. (2009) membuktikan bahwa profitabilitas mempunyai pengaruh positif signifikan terhadap tingkat pengungkapan tanggung jawab sosial yang sesuai dengan prinsip Islam.

Pijourlet (2013) dalam Nugraheni dan Permatasari (2016), berpendapat bahwa semakin tinggi rasio leverage, berarti semakin banyak kegiatan perusahaan dibiayai oleh hutang dibandingkan dengan modal dari pemilik. Oleh karena itu, kreditur juga akan memberikan perhatian yang lebih kepada perusahaan karena berkepentingan dengan kemampuan perusahaan untuk membayar kewajibannya. Pengungkapan CSR tidak akan banyak dilakukan oleh perusahaan karena perhatian perusahaan akan condong pada bagaimana dapat mengembalikan utang kepada kreditur. 
Penelitian ini dilakukan berdasarkan inkonsistensi dari hasil penelitian terdahulu mengenai pengaruh dewan pengawas syariah, profitabilitas dan leverage terhadap pengungkapan Islamic Social Reporting (ISR). Menurut Ningrum et al. (2013), Ramadhani (2016), Purwanti (2016), dan Mahdalena (2017) menunjukkan bahwa dewan pengawas syariah berpengaruh terhadap pengungkapan ISR. Sedangkan penelitian yang dilakukan oleh Khoirudin (2013) dan Maharani dan Yuliyanto (2016) hasilnya menunjukkan bahwa dewan pengawas syariah tidak berpengaruh terhadap pengungkapan ISR.

Penelitian yang dilakukan oleh Othman et al. (2009), Widiawati dan Raharja (2012), Wulandari (2015), dan Widarto (2017) menunjukkan bahwa profitabilitas berpengaruh terhadap pengungkapan ISR. Penelitian lain yang meneliti tentang profitabilitas dan leverage yang dilakukan oleh Anggraini dan Wulan (2015) hasilnya menunjukkan bahwa profitabilitas dan leverage berpengaruh terhadap pengungkapan ISR. Hal ini bertentangan dengan penelitian yang dilakukan oleh Lestari (2015) yang menunjukkan bahwa profitabilitas dan leverage tidak berpengaruh terhadap pengungkapan ISR. Penelitian yang sama dengan hasil yang berbeda yaitu penelitian yang dilakukan oleh Astuti (2014) dan Ramadhani (2016) menunjukkan bahwa profitabilitas tidak berpengaruh terhadap pengungkapan ISR, sedangkan leverage berpengaruh terhadap pengungkapan ISR. Penelitian yang dilakukan oleh Eksandy dan Hakim (2015) pun memiliki hasil yang berbeda, yaitu bahwa profitabilitas berpengaruh terhadap pengungkapan ISR, sedangkan leverage tidak berpengaruh terhadap pengungkapan ISR.

\section{LANDASAN TEORI DAN PENGEMBANGAN HIPOTESIS}

\subsection{Landasan Teori}

\subsubsection{Shariah Enterprise Theory}

Menurut Triyuwono (2009), enterprise theory merupakan teori yang mengakui adanya pertanggungjawaban tidak hanya kepada pemilik perusahaan (stakeholders) saja melainkan kepada kelompok stakeholders yang lebih luas. Enterprise theory kemudian dikembangkan agar teori tersebut lebih dekat dengan konsep syariah sehingga terbentuk teori yang dikenal dengan istilah Shariah Enterprise Theory (SET).

Dalam shariah enterprise theory, Slamet (2001:266) dalam Triyuwono (2009:352) menjelaskan, aksioma terpenting yang harus mendasari dalam setiap penetapan konsepnya adalah Allah sebagai Pencipta dan Pemilik Tunggal dari seluruh sumber daya yang ada di dunia ini. Maka yang berlaku dalam shariah enterprise theory adalah Allah sebagai sumber amanah utama, karena Dia adalah pemilik yang tunggal dan mutlak. Sedangkan sumber daya yang dimiliki oleh para stakeholders pada prinsipnya adalah amanah dari Allah yang didalamnya melekat sebuah tanggung jawab untuk menggunakan dengan cara dan tujuan yang ditetapkan oleh Sang Pemberi Amanah. 
Pada prinsipnya shariah enterprise theory memberikan bentuk pertanggungjawaban kepada Allah (vertikal) yang kemudian dijabarkan lagi pada bentuk pertanggungjawaban (horizontal) pada umat manusia dan lingkungan alam. Dalam pandangan shariah enterprise theory, stakeholders sebagai khalifah diberi amanah untuk mengelola sumber daya dan mendistribusikannya kepada seluruh makhluk di muka bumi secara adil (Slamet, 2001:268 dalam Triyuwono, 2009:354).

\subsubsection{Teori Legitimasi}

Legitimasi adalah persepsi umum atau asumsi yang menjelaskan bahwa tindakan entitas adalah sesuatu yang diharapkan, pantas, dan berkesesuaian dengan sistem norma, nilai, dan keyakinan, definisi yang di bangun di dalam masyarakat. Sehingga jika perusahaan telah bertindak bertentangan dengan halhal yang diharapkan, pantas, dan berkesesuaian dengan sistem sosial masyarakatnya maka perusahaan tersebut akan kehilangan legitimasinya (Suchman, 1995 dalam Lindrianasari, 2010).

Dalam teori legitimasi, dinyatakan bahwa suatu perusahaan akan secara sukarela melaporkan segala aktivitasnya jika itu memang yang diharapkan oleh komunitas untuk menjamin operasi perusahaan berada dalam batas dan norma yang berlaku di masyarakat. Oleh karena itu, pengungkapan Corporate Social Responsibility (CSR) yang dilakukan oleh perusahaan dapat diartikan sebagai alat bagi perusahaan untuk berperilaku dalam koridor-koridor yang secara sosial dapat diterima oleh lingkungan dan masyarakat (Putri, 2016:23).

Teori legitimasi didasarkan pada pengertian kontrak sosial yang diimplikasi antara institusi sosial dan masyarakat. Menurut teori legitimasi perusahaan dianjurkan untuk memberikan atau mengungkapkan bahwa kinerjanya dapat diterima oleh masyarakat (Maharani dan Yuliyanto, 2016).

\subsubsection{Teori Keagenan}

Teori keagenan mengungkapkan adanya hubungan antara principal (pemilik perusahaan atau pihak yang memberikan mandat/investor/pemegang saham) dan agent (manajer perusahaan atau pihak yang menerima mandat/manajemen) yang dilandasi dari adanya pemisahan kepemilikan dan pengendalian perusahaan, pemisahan penanggung resiko, pembuatan keputusan dan pengendalian fungsi-fungsi (Jensen \& Meckling, 1976 dalam Santoso dan Dhiyaul-Haq, 2017).

Prinsip utama teori ini pada dasarnya menyatakan hubungan kerja antara pihak yang memberi wewenang (principal) yakni pemilik atau pemegang saham dengan pihak yang menerima wewenang (agent) yakni manajemen atau pengelola (Sari dan Padmono, 2014).

Jensen dan Meckling (1976) dalam Santoso dan Dhiyaul-Haq (2017) menyatakan hubungan keagenan adalah suatu kontrak dimana satu atau lebih orang (principal) melibatkan orang lain (agent) untuk melakukan beberapa 
layanan atas nama mereka yang melibatkan agen untuk mendelegasikan sebagian kewenangan pengambilan keputusan.

\subsection{Pengembangan Hipotesis}

\subsubsection{Dewan Pengawas Syariah}

Perbedaan mendasar antara institusi finansial konvensional dan institusi finansial Islam adalah adanya dewan pengawas syariah. Adanya dewan pengawas syariah ini merupakan sebuah upaya untuk meningkatkan tata kelola perusahaan pada institusi Islam. Fungsi utama dewan ini adalah untuk mengarahkan, meninjau dan mengawasi kegiatan bank syariah. DPS mempunyai peran dalam pengungkapan ISR perbankan syariah. Hal ini karena dewan pengawas syariah mempunyai wewenang mengawasi kepatuhan perusahaan terhadap prinsip syariah. Oleh karena itu, semakin banyak dewan pengawas syariah maka semakin efektif pula pengawasan terhadap pengungkapan ISR dengan prinsip syariah. Apabila pelaksanaan tugas dan tanggung jawab dewan pengawas syariah telah dilakukan dengan baik, maka pengungkapan ISR dalam laporan tahunan akan baik.

H1: Dewan pengawas syariah berpengaruh positif signifikan terhadap

Pengungkapan Islamic Social Reporting (ISR).

\subsubsection{Profitabilitas}

Semakin besar nilai rasio profitabilitas menunjukkan tingkat profitabilitas usaha bank semakin baik atau sehat. Apabila bank sedang mendapatkan keuntungan yang tinggi maka manajemen akan termotivasi untuk mengungkapkan informasi secara rinci. Bank dengan profitabilitas yang tinggi melakukan pengungkapan sebagai bentuk akuntabilitas dan transparansi kepada para pemilik modal atas dana-dana yang telah diinvestasikan. Sehingga bank yang memiliki tingkat profitabilitas yang tinggi cenderung akan mengungkapkaan tanggung jawab sosialnya.

H2: Profitabilitas berpengaruh positif signifikan terhadap pengungkapan Islamic Social Reporting (ISR).

\subsubsection{Leverage}

Tingkat leverage adalah untuk melihat kemampuan perusahaan dalam menyelesaikan semua kewajibannya kepada pihak lain. Leverage berkaitan dengan bagaimana perusahaan didanai. Karena sebuah perusahaan dapat melakukan pendanaan melalui dua cara yaitu melalui pemegang saham atau melalui kreditur dengan meminjam dana, kedua cara ini dapat mempengaruhi tingkat pengungkapan perusahaan. Perusahaan harus menjelaskan kepada investor, kreditor ataupun pihak berkepentingan lainnya mengenai kemampuan mereka untuk membayar hutang dan dampak pinjaman tersebut dalam kegiatan perusahaan. Perusahaan dengan tingkat leverage yang tinggi cenderung tidak akan banyak melakukan pengungkapan, karena perusahaan akan lebih memperhatikan bagaimana dapat mengembalikan utang kepada kreditur.

H3: Leverage berpengaruh positif signifikan terhadap pengungkapan Islamic Social Reporting (ISR). 


\section{METODE PENELITIAN}

\subsection{Metode Pengumpulan Data}

Jenis data yang digunakan dalam penelitian ini adalah data sekunder. Teknik yang digunakan untuk memperoleh data dan informasi yang dibutuhkan dalam penelitian ini adalah dengan menggunakan teknik dokumentasi, yaitu mengumpulkan, mencatat, dan mengkaji data sekunder yang berupa laporan tahunan (annual report) perusahaan dan informasi lain yan dapat diakses secara publik.

Populasi dalam penelitian ini adalah seluruh Bank Umum Syariah di Indonesia dengan laporan tahunan (annual report) selama 5 periode yaitu dari tahun 2012 sampai 2016. Populasi penelitian sebanyak 12 Bank Umum Syariah. Sampel yang digunakan dalam penelitian ini adalah Bank Umum Syariah yang dipilih berdasarkan metode purposive sampling yaitu penentuan sampel dari populasi yang ada berdasarkan kriteria. Total sampel yang diteliti adalah sebanyak 9 Bank Umum Syariah.

\subsection{Operasionalisasi Variabel}

Variabel yang digunakan dalam penelitian yaitu variabel independen dan variabel dependen. Variabel independen terdiri dari dewan pengawas syariah yang diukur dengan menggunakan variabel dummy, profitabilitas diukur dengan Return On Asset dan leverage diukur dengan Debt to Equity Ratio. Serta Variabel dependen yaitu pengungkapan Islamic Social Reporting (ISR).

Tabel 1. Operasionalisasi Variabel

\begin{tabular}{|c|c|c|c|}
\hline Variabel & Konsep Variabel & Indikator & Skala \\
\hline $\begin{array}{l}\text { Dewan } \\
\text { Pengewas } \\
\text { Syariah } \\
\left(x_{1}\right)\end{array}$ & $\begin{array}{l}\text { Dewan Pengawas } \\
\text { Syariah (DPS) } \\
\text { adalah suatu } \\
\text { badan yang diberi } \\
\text { wewenang untuk } \\
\text { melakukan } \\
\text { supervisi atau } \\
\text { pengawasan dan } \\
\text { melihat secara } \\
\text { dekat aktivitas } \\
\text { lembaga } \\
\text { keuangan syariah } \\
\text { agar lembaga } \\
\text { tersebut } \\
\text { senantiasa } \\
\text { mengikuti aturan } \\
\text { dan prinsip-prinsip } \\
\text { syariah. } \\
\text { Sumber: Faozan }\end{array}$ & $\begin{array}{l}\text { Apabila Bank Syariah memiliki jumlah } \\
\text { dewan pengawas syariah sebanyak } \\
\text { tiga orang atau lebih, maka akan } \\
\text { diberi nilai } 1 \text {, jika tidak maka akan } \\
\text { diberi nilai } 0 .\end{array}$ & $\begin{array}{l}\text { Nomi } \\
\text { nal }\end{array}$ \\
\hline
\end{tabular}


ISSN

2460-030X
Jurnal Akuntansi Bisnis dan Ekonomi

Volume 4 No. 2, September 2018

\begin{tabular}{|c|c|c|c|}
\hline & $(2014: 26)$ & & \\
\hline $\begin{array}{l}\text { Profitabilita } \\
\mathrm{s}\left(x_{2}\right)\end{array}$ & $\begin{array}{l}\text { Rasio profitabilitas } \\
\text { adalah rasio yang } \\
\text { menunjukkan } \\
\text { tingkat efektivitas } \\
\text { yang dicapai } \\
\text { melalui usaha } \\
\text { operasional bank. } \\
\text { Sumber: } \\
\text { Muhammad } \\
(2015: 254)\end{array}$ & Return on Assets $(\mathrm{ROAA})=\frac{\text { Laba Sebelum Pajak }}{\text { Total Aset }} \times 100 \%$ & Rasio \\
\hline $\begin{array}{l}\text { Leverage } \\
\left(x_{a}\right)\end{array}$ & $\begin{array}{l}\text { Rasio leverage } \\
\text { dapat melihat } \\
\text { seberapa jauh } \\
\text { perusahaan } \\
\text { dibiayai oleh } \\
\text { hutang atau pihak } \\
\text { luar dengan } \\
\text { kemampuan } \\
\text { perusahaan yang } \\
\text { digambarkan oleh } \\
\text { modal (equity). } \\
\text { Perusahaan yang } \\
\text { baik mestinya } \\
\text { memiliki } \\
\text { komposisi modal } \\
\text { yang lebih besar } \\
\text { dari hutang. } \\
\text { Sumber: Harahap } \\
\text { (1999:306) }\end{array}$ & Debt to Equity Ratio $=\frac{\text { Total Hutang (Debt) }}{\text { Ekuitas (Equity) }}$ & Rasio \\
\hline
\end{tabular}

Tabel 1. Operasionalisasi Variabel (Lanjutan)

\begin{tabular}{|c|c|c|c|}
\hline Variabel & Konsep Variabel & Indikator & Skala \\
\hline $\begin{array}{l}\text { Pengungka } \\
\text { pan Islamic } \\
\text { Social } \\
\text { Reporting } \\
\text { (ISR) (Y) }\end{array}$ & $\begin{array}{l}\text { ISR adalah } \\
\text { standar pelaporan } \\
\text { kinerja sosial } \\
\text { perusahaan- } \\
\text { perusahaan yang } \\
\text { berbasis syariah. }\end{array}$ & 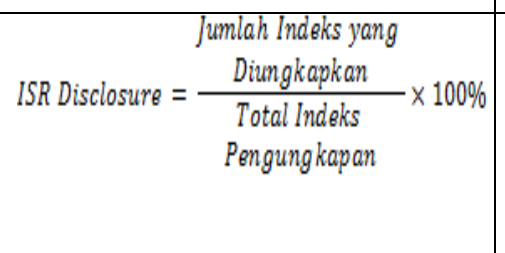 & Rasio \\
\hline
\end{tabular}




\subsection{Pengujian Hipotesis}

Pengujian hipotesis dalam penelitian ini menggunakan analisis regresi linear berganda. Persamaan ini disusun untuk mengetahui adanya pengaruh variabel independen terhadap variabel dependen.

Hipotesis secara simultan:

$H_{0}: \beta_{1}=\beta_{2}=\beta_{a}=0$, bahwa secara bersama-sama, dewan pengawas syariah, profitabilitas, dan leverage tidak berpengaruh signifikan terhadap pengungkapan Islamic Social Reporting (ISR).

$H_{A}: \beta_{1} \neq \beta_{2} \neq \beta_{3} \neq 0$, bahwa secara bersama-sama, dewan pengawas syariah, profitabilitas, dan leverage berpengaruh signifikan terhadap pengungkapan Islamic Social Reporting (ISR).

Hipotesis secara individual:

1. Dewan Pengawas Syariah

$H_{0}: \beta_{1}=0_{x} \quad$ maka dewan pengawas syariah tidak berpengaruh signifikan terhadap pengungkapan Islamic Social Reporting (ISR).

$H_{A}: \beta_{1}>0$, maka dewan pengawas syariah berpengaruh positif signifikan terhadap pengungkapan Islamic Social Reporting (ISR).

2. Profitabilitas

$H_{0}: \beta_{2}=0_{x} \quad$ maka profitabilitas tidak berpengaruh signifikan terhadap pengungkapan Islamic Social Reporting (ISR).

$H_{A}: \beta_{2}>0$, maka profitabilitas berpengaruh positif signifikan terhadap pengungkapan Islamic Social Reporting (ISR).

3. Leverage

$H_{0}: \beta_{a}=0, \quad$ maka leverage tidak berpengaruh signifikan terhadap pengungkapan Islamic Social Reporting (ISR).

$H_{A}: \beta_{a}<0$, maka leverage berpengaruh negatif signifikan terhadap pengungkapan Islamic Social Reporting (ISR).

\subsection{Metode Analisis Data}

Analisis regresi berganda digunakan oleh peneliti karena dalam penelitian ini terdiri dari satu variabel dependen dan tiga variabel independen. Berdasarkan pengertian di atas, persamaan regresi yang digunakan dalam penelitian adalah sebagai berikut:

$$
\mathrm{Y}=\alpha+\beta_{1} D P S+\beta_{2} R O A+\beta_{2} D E R+e
$$

Dimana:

ISR = Pengungkapan Islamic Social Reporting (ISR)

$\alpha \quad=$ Konstanta

$\beta_{1} \quad=$ Koefisien regresi dari dewan pengawas syariah

$\beta_{2} \quad=$ Koefisien regresi dari profitabilitas

$\beta_{a} \quad=$ Koefisien regresi dari leverage 
ISSN

2460-030X

$$
\begin{array}{ll}
\text { DPS } & =\text { Dewan pengawas syariah } \\
R O A & =\text { Profitabilitas } \\
D E R & =\text { Leverage } \\
e & =\text { Error }
\end{array}
$$

\section{HASIL DAN PEMBAHASAN}

\subsection{Analisis Deskriptif}

Untuk mengetahui pengaruh dewan pengawas syariah, profitabilitas, dan leverage terhadap pengungkapan Islamic Social Reporting (ISR) pada Bank Umum Syariah periode 2012 sampai dengan 2016, maka dilakukan perhitungan statistik terhadap data-data yang diperoleh. Statistik yang digunakan dalam penelitian ini menggunakan statistik deskriptif, dalam hal ini statistik berhubungan dengan pengumpulan, peringkasan data dan penyajian dari peringkasan data tersebut. Data tersebut akan diuraikan atas kelompok kategorikategorinya.

\subsubsection{Dewan Pengawas Syariah}

Dewan pengawas syariah bertugas memberikan nasihat dan saran kepada direksi serta mengawasi kegiatan bank agar sesuai dengan prinsip syariah, semakin banyak jumlah dewan pengawas syariah, maka akan semakin efektif pengawasan terhadap pengungkapan ISR sesuai dengan prinsip syariah. Dewan pengawas syariah ini dapat diukur dengan jumlah dewan pengawas syariah pada Bank Umum Syariah tersebut, apabila Bank Umum Syariah memiliki jumlah dewan pengawas syariah sebanyak 3 orang atau lebih, maka akan diberi nilai 1 , jika tidak maka akan diberi nilai 0 . Tabel dibawah ini merupakan jumlah dewan pengawas syariah untuk 9 Bank Umum Syariah yang menjadi sampel penelitian yang dilakukuan:

Tabel 4.4.

Jumlah Dewan Pengawas Syariah

Bank Umum Syariah Periode 2012-2016

\begin{tabular}{|r|l|c|c|c|c|c|}
\hline \multirow{2}{*}{ No. } & \multirow{2}{*}{ Nama Bank Umum Syariah } & \multicolumn{5}{|c|}{ Tahun } \\
\cline { 3 - 7 } & & $\mathbf{2 0 1 2}$ & $\mathbf{2 0 1 3}$ & $\mathbf{2 0 1 4}$ & $\mathbf{2 0 1 5}$ & $\mathbf{2 0 1 6}$ \\
\hline 1. & PT Bank BCA Syariah & 0 & 0 & 0 & 0 & 0 \\
\hline 2. & PT Bank BNI Syariah & 0 & 0 & 0 & 0 & 0 \\
\hline 3. & PT Bank BRI Syariah & 0 & 0 & 0 & 0 & 0 \\
\hline 4. & PT Bank Maybank Syariah Indonesia & 0 & 0 & 0 & 0 & 0 \\
\hline 5. & PT Bank Mega Syariah & 1 & 1 & 1 & 1 & 1 \\
\hline 6. & PT Bank Muamalat Indonesia & 1 & 1 & 1 & 1 & 1 \\
\hline 7. & PT Bank Panin Syariah & 0 & 0 & 0 & 0 & 0 \\
\hline 8. & PT Bank Syariah Bukopin & 0 & 0 & 0 & 0 & 0 \\
\hline 9. & PT Bank Syariah Mandiri & 1 & 1 & 1 & 1 & 1 \\
\hline
\end{tabular}

Sumber: Data diolah oleh Penulis 
Dari tabel di atas menunjukkan bahwa bank umum syariah yang memiliki dewan pengawas syariah berjumlah 3 orang berturut-turut selama 5 tahun yaitu dari tahun 2012 sampai dengan tahun 2016 adalah PT Bank Mega Syariah, PT Bank Muamalat Indonesia dan PT Bank Syariah Mandiri, sedangkan sisanya berjumlah 2 orang.

\subsubsection{Profitabilitas}

Bank dengan profitabilitas yang tinggi akan memberikan informasi yang lebih rinci. Profitabilitas dapat diukur dengan persentase perbandingan antara laba sebelum pajak dengan total aset. Hasil perhitungan profitabilitas yang dijadikan sampel penelitian disajikan dalam tabel berikut ini:

Tabel 4.5.

Tingkat Profitabilitas

Bank Umum Syariah Periode 2012-2016

\begin{tabular}{|c|c|c|c|c|c|c|c|}
\hline \multirow{2}{*}{ No } & \multirow{2}{*}{$\begin{array}{c}\text { Nama Bank Umum } \\
\text { Syariah }\end{array}$} & \multicolumn{5}{|c|}{ Tahun } & \multirow[t]{2}{*}{$\begin{array}{l}\text { Rata- } \\
\text { rata }\end{array}$} \\
\hline & & 2012 & 2013 & 2014 & 2015 & 2016 & \\
\hline 1. & PT Bank BCA Syariah & $0,8 \%$ & $1,0 \%$ & $0,8 \%$ & $1,0 \%$ & $1,1 \%$ & $0,9 \%$ \\
\hline 2. & PT Bank BNI Syariah & $1,48 \%$ & $1,37 \%$ & $1,27 \%$ & $1,43 \%$ & $1,44 \%$ & $1,40 \%$ \\
\hline 3. & PT Bank BRI Syariah & $0,88 \%$ & $1,15 \%$ & $0,08 \%$ & $0,77 \%$ & $0,95 \%$ & $0,77 \%$ \\
\hline 4. & $\begin{array}{l}\text { PT Bank Maybank } \\
\text { Syariah Indonesia }\end{array}$ & $2,88 \%$ & $2,87 \%$ & $3,61 \%$ & $20,13 \%$ & $-9,51 \%$ & $-4,06 \%$ \\
\hline 5. & $\begin{array}{l}\text { PT Bank Mega } \\
\text { Syariah }\end{array}$ & $3,81 \%$ & $2,33 \%$ & $0,29 \%$ & $0,30 \%$ & $2,63 \%$ & $1,87 \%$ \\
\hline 6. & $\begin{array}{l}\text { PT Bank Muamalat } \\
\text { Indonesia }\end{array}$ & $1,54 \%$ & $0,50 \%$ & $0,17 \%$ & $0,20 \%$ & $0,22 \%$ & $0,53 \%$ \\
\hline 7. & $\begin{array}{l}\text { PT Bank Panin } \\
\text { Syariah }\end{array}$ & $3,29 \%$ & $1,03 \%$ & $1,99 \%$ & $1,14 \%$ & $0,37 \%$ & $1,56 \%$ \\
\hline 8. & $\begin{array}{l}\text { PT Bank Syariah } \\
\text { Bukopin }\end{array}$ & $0,55 \%$ & $0,69 \%$ & $0,27 \%$ & $0,79 \%$ & $0,76 \%$ & $0,61 \%$ \\
\hline 9. & $\begin{array}{l}\text { PT Bank Syariah } \\
\text { Mandiri }\end{array}$ & $2,25 \%$ & $1,53 \%$ & $-0,04 \%$ & $0,56 \%$ & $0,59 \%$ & $0,98 \%$ \\
\hline & Nilai Minimum (MIN) & $0,55 \%$ & $0,50 \%$ & $-0,04 \%$ & $20,13 \%$ & $-9,51 \%$ & $-4,06 \%$ \\
\hline & Vilai Maksimum (MAX) & $3,81 \%$ & $2,87 \%$ & $3,61 \%$ & $1,43 \%$ & $2,63 \%$ & $1,87 \%$ \\
\hline & Rata-rata (MEAN) & $1,94 \%$ & $1,39 \%$ & $0,94 \%$ & $-1,55 \%$ & $-0,16 \%$ & $0,51 \%$ \\
\hline
\end{tabular}

Sumber: Data diolah oleh Penulis

Berdasarkan tabel di atas, secara keseluruhan Bank Umum Syariah dari tahun 2012 sampai dengan 2016 yang memiliki tingkat profitabilitas tertinggi adalah PT Bank Mega Syariah dengan rata-rata nilai tingkat profitabilitas sebesar 1,87\%. Sedangkan Bank Umum Syariah yang memiliki tingkat profitabilitas terendah adalah PT Bank Maybank Syariah Indonesia dengan rata-rata nilai tingkat profitabilitas sebesar $-4,06 \%$. 
Pada tahun 2012 bank yang memiliki tingkat profitabilitas terendah adalah PT Bank Syariah Bukopin yaitu sebesar $0,55 \%$ dan bank dengan tingkat profitabilitas tertinggi adalah PT Bank Mega Syariah yaitu sebesar 3,81\%. Nilai rata-ratanya sebesar $1,94 \%$.

Pada tahun 2013, bank yang memiliki tingkat profitabilitas terendah adalah PT Bank Muamalat Indonesia yaitu sebesar 0,50\% dan bank dengan tingkat profitabilitas tertinggi adalah PT Bank Maybank Syariah Indonesia yaitu sebesar $2,87 \%$. Nilai rata-ratanya sebesar $1,39 \%$.

Pada tahun 2014, bank yang memiliki tingkat profitabilitas terendah adalah PT Bank Syariah Mandiri yaitu sebesar $-0,04 \%$ dan bank dengan tingkat profitabilitas tertinggi adalah PT Bank Maybank Syariah Indonesia yaitu sebesar $3,61 \%$. Nilai rata-ratanya sebesar $0,94 \%$.

Pada tahun 2015, bank yang memiliki tingkat profitabilitas terendah adalah PT Bank Maybank Syariah Indonesia yaitu sebesar -20,13\% dan bank dengan tingkat profitabilitas tertinggi adalah PT Bank BNI Syariah yaitu sebesar 1,43\%. Nilai rata-ratanya sebesar $-1,55 \%$.

Pada tahun 2016, bank yang memiliki tingkat profitabilitas terendah adalah PT Bank Maybank Syariah Indonesia yaitu sebesar $-9,51 \%$ dan bank dengan tingkat profitabilitas tertinggi adalah PT Bank Mega Syariah yaitu sebesar 2,63\%. Nilai rata-ratanya sebesar $-0,16 \%$.

Bank Umum Syariah yang memiliki ROA tinggi merupakan bank dengan total aset yang dapat memberikan atau menghasilkan laba yang lebih efektif dibandingkan bank yang ROAnya lebih rendah. Bank Umum Syariah yang memiliki ROA lebih rendah merupakan bank dengan total aset yang kurang memberikan atau menghasilkan laba yang efektif.

\subsubsection{Leverage}

Bank dengan rasio leverage yang tinggi cenderung tidak akan banyak melakukan pengungkapan CSR, karena bank akan fokus pada bagaimana dapat melunasi kewajibannya. Leverage dapat diukur dengan persentase perbandingan antara total hutang dengan total ekuitas. Hasil perhitungan leverage yang dijadikan sampel penelitian disajikan dalam tabel berikut ini:

Tabel 4.6.

Tingkat Leverage

Bank Umum Syariah Periode 2012-2016

\begin{tabular}{|c|c|c|c|c|c|c|c|}
\hline \multirow[t]{2}{*}{ No } & \multirow{2}{*}{ Nama Bank Umum Syariah } & \multicolumn{5}{|c|}{ Tahun } & \multirow[t]{2}{*}{$\begin{array}{l}\text { Rat } \\
\text { a- } \\
\text { rata }\end{array}$} \\
\hline & & 2012 & 2013 & $\begin{array}{c}201 \\
4\end{array}$ & $\begin{array}{c}201 \\
5\end{array}$ & $\begin{array}{c}201 \\
6\end{array}$ & \\
\hline 1. & PT Bank BCA Syariah & 0,844 & 0,877 & $\begin{array}{r}0,51 \\
8\end{array}$ & $\begin{array}{r}0,37 \\
4\end{array}$ & $\begin{array}{r}0,38 \\
2\end{array}$ & $\begin{array}{r}0,59 \\
9\end{array}$ \\
\hline 2. & PT Bank BNI Syariah & 1,841 & 2,942 & $\begin{array}{r}1,58 \\
2\end{array}$ & $\begin{array}{r}1,49 \\
4\end{array}$ & $\begin{array}{r}1,88 \\
4\end{array}$ & $\begin{array}{r}1,94 \\
9\end{array}$ \\
\hline 3. & PT Bank BRI Syariah & 3,212 & 2,653 & $\begin{array}{r}3,28 \\
4\end{array}$ & $\begin{array}{r}2,74 \\
4\end{array}$ & $\begin{array}{r}3,37 \\
2\end{array}$ & $\begin{array}{r}3,05 \\
3\end{array}$ \\
\hline
\end{tabular}




\begin{tabular}{|c|c|c|c|c|c|c|c|}
\hline 4 & $\begin{array}{l}\text { PT Bank Maybank Syariah } \\
\text { Indonesia }\end{array}$ & 0,353 & 0,207 & $\begin{array}{r}0,14 \\
8\end{array}$ & $\begin{array}{r}0,36 \\
5\end{array}$ & $\begin{array}{r}0,54 \\
6\end{array}$ & $\begin{array}{r}0,32 \\
4\end{array}$ \\
\hline 5. & PT Bank Mega Syariah & 3,412 & 2,474 & $\begin{array}{r}1,64 \\
1\end{array}$ & $\begin{array}{r}1,06 \\
9\end{array}$ & $\begin{array}{r}6,15 \\
9\end{array}$ & $\begin{array}{r}2,95 \\
1\end{array}$ \\
\hline 6. & PT Bank Muamalat I & ,302 & 2,301 & $\begin{array}{r}2,35 \\
2 \\
\end{array}$ & $\begin{array}{r}2,52 \\
1\end{array}$ & $\begin{array}{r}2,61 \\
9\end{array}$ & $\begin{array}{r}2,61 \\
9\end{array}$ \\
\hline 7. & PT Bank Pani & 429 & ,765 & $\begin{array}{r}0,83 \\
1 \\
\end{array}$ & $\begin{array}{r}0,72 \\
8\end{array}$ & $\begin{array}{r}0,85 \\
8\end{array}$ & $\begin{array}{r}0,72 \\
2 \\
\end{array}$ \\
\hline 8. & PT Bank Syari & $\begin{array}{r}12,24 \\
2\end{array}$ & $\begin{array}{r}13,84 \\
2\end{array}$ & $\begin{array}{r}1,65 \\
5\end{array}$ & $\begin{array}{r}1,38 \\
4\end{array}$ & $\begin{array}{r}1,64 \\
6\end{array}$ & $\begin{array}{r}6,15 \\
4\end{array}$ \\
\hline 9. & PT Bank Syariah Mandiri & 2,193 & 2,269 & $\begin{array}{r}1,68 \\
7\end{array}$ & $\begin{aligned} 1,76 \\
1\end{aligned}$ & $\begin{array}{r}1,75 \\
7\end{array}$ & $\begin{array}{r}1,93 \\
3\end{array}$ \\
\hline & Nilai $\mathrm{N}$ & & 207 & $\begin{array}{r}0,14 \\
8\end{array}$ & $\begin{array}{r}0,36 \\
5\end{array}$ & $\begin{array}{r}0,38 \\
2\end{array}$ & $\begin{array}{r}0,32 \\
4\end{array}$ \\
\hline & Nilai Maksimum (MAX) & $\begin{array}{r}12,24 \\
2\end{array}$ & $\begin{array}{r}13,84 \\
2\end{array}$ & $\begin{array}{r}3,28 \\
4\end{array}$ & $\begin{array}{r}2,74 \\
4\end{array}$ & $\begin{array}{r}6,15 \\
9\end{array}$ & $\begin{array}{r}6,15 \\
4\end{array}$ \\
\hline & ata-ra & 3,092 & 3,148 & $\begin{array}{r}1,52 \\
2 \\
\end{array}$ & $\begin{array}{r}1,38 \\
2 \\
\end{array}$ & $\begin{array}{r}2,13 \\
6 \\
\end{array}$ & 2,25 \\
\hline
\end{tabular}

Sumber: Data diolah oleh Penulis

Berdasarkan tabel di atas, secara keseluruhan Bank Umum Syariah dari tahun 2012 sampai dengan 2016 yang memiliki tingkat leverage tertinggi adalah PT Bank Syariah Bukopin dengan rata-rata nilai tingkat leverage sebesar 6,154. Sedangkan Bank Umum Syariah yang memiliki tingkat leverage terendah adalah PT Bank Maybank Syariah Indonesia dengan rata-rata nilai tingkat leverage sebesar 0,324.

Pada tahun 2012 bank yang memiliki tingkat leverage terendah adalah PT Bank Maybank Syariah Indonesia yaitu sebesar 0,353 dan bank dengan tingkat leverage tertinggi adalah PT Bank Syariah Bukopin yaitu sebesar 12,242. Nilai rata-ratanya sebesar 3,092.

Pada tahun 2013, bank yang memiliki tingkat leverage terendah adalah PT Bank Maybank Syariah Indonesia yaitu sebesar 0,207 dan bank dengan tingkat leverage tertinggi adalah PT Bank Syariah Bukopin yaitu sebesar 13,842. Nilai rata-ratanya sebesar 3,148 .

Pada tahun 2014, bank yang memiliki tingkat leverage terendah adalah PT Bank Maybank Syariah Indonesia yaitu sebesar 0,148 dan bank dengan tingkat leverage tertinggi adalah PT Bank BRI Syariah yaitu sebesar 3,284. Nilai rataratanya sebesar 1,522 .

Pada tahun 2015, bank yang memiliki tingkat leverage terendah adalah PT Bank Maybank Syariah Indonesia yaitu sebesar 0,365 dan bank dengan tingkat leverage tertinggi adalah PT Bank BRI Syariah yaitu sebesar 2,744. Nilai rataratanya sebesar 1,382.

Pada tahun 2016, bank yang memiliki tingkat leverage terendah adalah PT Bank BCA Syariah yaitu sebesar 0,382 dan bank dengan tingkat leverage tertinggi adalah PT Bank Mega Syariah yaitu sebesar 6,159. Nilai rata-ratanya sebesar 2,136 . 
ISSN

2460-030X

Bank Umum Syariah yang memiliki DER rendah merupakan bank dengan modal yang dapat membayar atau meminimalisir kewajibannya lebih efektif dibandingkan bank yang DERnya lebih tinggi. Bank Umum Syariah yang memiliki DER tinggi merupakan bank dengan modal yang kurang efektif dalam membayar atau meminimalisir kewajibannya. Artinya setiap Rp. 1,- modal sendiri dapat menjamin sebesar tingkat hutang yang dimiliki.

\subsubsection{Pengungkapan Islamic Social Reporting (ISR)}

Islamic Social Reporting (ISR) adalah suatu indeks yang mengukur tingkat pengungkapan sosial yang sesuai prinsip syariah yang disampaikan perusahaan pada laporan tahunannya. Pengungkapan Islamic Social Reporting (ISR) dapat diukur dengan jumlah indeks yang diungkapkan dibagi total indeks pengungkapan. Hasil perhitungan pengungkapan Islamic Social Reporting (ISR) yang dijadikan sampel penelitian disajikan dalam tabel berikut ini:

Tabel 4.7.

Tingkat Pengungkapan Islamic Social Reporting (ISR) Bank Umum Syariah Periode 2012-2016

\begin{tabular}{|c|c|c|c|c|c|c|c|}
\hline \multirow{2}{*}{ No } & \multirow{2}{*}{ Nama Bank Umum Syariah } & \multicolumn{5}{|c|}{ Tahun } & \multirow[t]{2}{*}{$\begin{array}{l}\text { Rata } \\
\text {-rata }\end{array}$} \\
\hline & & $\begin{array}{c}201 \\
2\end{array}$ & $\begin{array}{c}201 \\
3\end{array}$ & $\begin{array}{c}201 \\
4\end{array}$ & $\begin{array}{c}201 \\
5\end{array}$ & $\begin{array}{c}201 \\
6\end{array}$ & \\
\hline 1. & PT Bank BCA Syariah & $63 \%$ & $\begin{array}{l}65 \\
\%\end{array}$ & $\begin{array}{l}65 \\
\%\end{array}$ & $\begin{array}{l}65 \\
\%\end{array}$ & $\begin{array}{l}69 \\
\%\end{array}$ & $65 \%$ \\
\hline 2. & PT Bank BNI Syariah & $56 \%$ & $\begin{array}{l}71 \\
\%\end{array}$ & $\begin{array}{r}73 \\
\%\end{array}$ & $\begin{array}{r}77 \\
\%\end{array}$ & $\begin{array}{r}83 \\
\%\end{array}$ & $72 \%$ \\
\hline 3. & PT Bank BRI Syariah & $58 \%$ & $\begin{array}{r}63 \\
\%\end{array}$ & $\begin{array}{l}58 \\
\%\end{array}$ & $\begin{array}{l}56 \\
\%\end{array}$ & $\begin{array}{l}75 \\
\%\end{array}$ & $62 \%$ \\
\hline 4. & $\begin{array}{l}\text { PT Bank Maybank Syariah } \\
\text { Indonesia }\end{array}$ & $44 \%$ & $\begin{array}{l}50 \\
\%\end{array}$ & $\begin{array}{r}50 \\
\%\end{array}$ & $\begin{array}{l}56 \\
\%\end{array}$ & $\begin{array}{l}52 \\
\%\end{array}$ & $50 \%$ \\
\hline 5. & PT Bank Mega Syariah & $60 \%$ & $\begin{array}{r}60 \\
\%\end{array}$ & $\begin{array}{r}60 \\
\%\end{array}$ & $\begin{array}{l}69 \\
\%\end{array}$ & $\begin{array}{r}77 \\
\%\end{array}$ & $65 \%$ \\
\hline 6. & PT Bank Muamalat Indonesia & $67 \%$ & $\begin{array}{r}73 \\
\%\end{array}$ & $\begin{aligned} 75 \\
\%\end{aligned}$ & $\begin{array}{l}75 \\
\%\end{array}$ & $\begin{array}{r}83 \\
\%\end{array}$ & $75 \%$ \\
\hline 7. & PT Bank Panin Syariah & $52 \%$ & $\begin{array}{r}60 \\
\%\end{array}$ & $\begin{array}{l}65 \\
\%\end{array}$ & $\begin{array}{r}65 \\
\%\end{array}$ & $\begin{array}{r}73 \\
\%\end{array}$ & $63 \%$ \\
\hline 8. & PT Bank Syariah Bukopin & $56 \%$ & $\begin{array}{r}54 \\
\% \\
\end{array}$ & $\begin{array}{r}54 \\
\%\end{array}$ & $\begin{array}{r}56 \\
\%\end{array}$ & $\begin{array}{l}65 \\
\% \\
\end{array}$ & $57 \%$ \\
\hline 9. & PT Bank Syariah Mandiri & $77 \%$ & $\begin{array}{r}79 \\
\%\end{array}$ & $\begin{array}{r}75 \\
\%\end{array}$ & $\begin{array}{l}85 \\
\%\end{array}$ & $\begin{array}{l}83 \\
\%\end{array}$ & $80 \%$ \\
\hline & Nilai Minimum (MIN) & $\begin{array}{r}44 \\
\%\end{array}$ & $\begin{array}{r}50 \\
\%\end{array}$ & $\begin{array}{r}50 \\
\%\end{array}$ & $\begin{array}{l}56 \\
\%\end{array}$ & $\begin{array}{r}52 \\
\%\end{array}$ & $50 \%$ \\
\hline & Nilai Maksimum (MAX) & $\begin{array}{r}77 \\
\%\end{array}$ & $\begin{array}{r}79 \\
\%\end{array}$ & $\begin{aligned} 75 \\
\%\end{aligned}$ & $\begin{array}{l}85 \\
\%\end{array}$ & $\begin{array}{l}83 \\
\%\end{array}$ & $80 \%$ \\
\hline & Rata-rata (MEAN) & 59 & 64 & 64 & 67 & 73 & $66 \%$ \\
\hline
\end{tabular}


Sumber: Data diolah oleh Penulis

Berdasarkan tabel di atas, secara keseluruhan Bank Umum Syariah dari tahun 2012 sampai dengan 2016 yang memiliki tingkat pengungkapan ISR tertinggi adalah PT Bank Syariah Mandiri dengan rata-rata nilai tingkat pengungkapan ISR sebesar $80 \%$. Sedangkan Bank Umum Syariah yang memiliki tingkat pengungkapan ISR terendah adalah PT Bank Maybank Syariah Indonesia dengan rata-rata nilai tingkat pengungkapan ISR sebesar $50 \%$.

Selama 5 tahun berturut-turut nilai terendah dari tingkat pengungkapan ISR adalah pada PT Bank Maybank Syariah Indonesia yaitu sebesar $44 \%, 50 \%$, $50 \%, 56 \%$, dan $52 \%$. Sedangkan untuk nilai tertinggi dari tingkat pengungkapan ISR selama 5 tahun berturut-turut adalah pada PT Bank Syariah Mandiri yaitu sebesar $77 \%, 79 \%, 75 \%, 85 \%$, dan $83 \%$. Nilai rata-rata dari tingkat pengungkapan ISR adalah sebesar 59\% pada tahun 2012, 64\% pada tahun 2013, 64\% pada tahun 2014, 67\% pada tahun 2015 dan 73\% pada tahun 2016 .

\subsection{Analisis Uji Statistik Penelitian}

Koefisien determinasi $\left(R^{2}\right)$ pada intinya mengukur seberapa jauh kemampuan model dalam menerangkan variasi variabel dependen. Semakin besar nilainya, maka menunjukkan bahwa persamaan regresi yang dihasilkan baik untuk mengestimasi variabel dependen. Hasil koefisien determinasi disajikan dalam tabel di bawah ini:

Tabel 4.16.

Hasil Koefisien Determinasi Model Summary ${ }^{\mathrm{b}}$

\begin{tabular}{|l|r|r|r|r|}
\hline Model & $\mathrm{R}$ & $\mathrm{R}$ Square & $\begin{array}{c}\text { Adjusted R } \\
\text { Square }\end{array}$ & $\begin{array}{c}\text { Std. Error of } \\
\text { the Estimate }\end{array}$ \\
\hline 1 &, $540^{\mathrm{a}}$ &, 291 &, 239 &, 09047 \\
\hline
\end{tabular}

a. Predictors: (Constant), DER, DPS, ROA

b. Dependent Variable: ISR

Sumber: Data diolah oleh Penulis

Hasil statistik di atas menunjukkan bahwa nilai koefisien determinasi $\left(R^{2}\right)$ adalah sebesar 0,291 hal ini berarti bahwa sebesar $29,1 \%$ variasi variabel dependen mampu dijelaskan oleh variabel independen yaitu dewan pengawas syariah, profitabilitas dan leverage dan sisanya $70,9 \%$ variabel dependen dipengaruhi oleh faktor-faktor eksternal selain dari variabel independen yang diteliti dalam penelitian ini.

\subsection{Uji Hipotesis Simultan (Uji F)}

Uji statistik F pada dasarnya menunjukkan apakah semua variabel independen atau bebas yang dimasukkan ke dalam model mempunyai pengaruh secara bersama-sama terhadap variabel dependen atau terikat. Hasil uji $\mathrm{F}$ ditunjukkan dalam tabel sebagai berikut: 
ISSN

2460-030X

Tabel 4.14.

Hasil Uji Signifikansi Simultan (Uji Statistik F)

ANOVA $^{\mathrm{a}}$

\begin{tabular}{|l|r|r|r|r|l|}
\hline Model & \multicolumn{1}{|c|}{$\begin{array}{c}\text { Sum of } \\
\text { Squares }\end{array}$} & Df & Mean Square & F & Sig. \\
\hline Regression &, 138 & 3 &, 046 & 5,617 &, $003^{\text {b }}$ \\
1 Residual &, 336 & 41 &, 008 & & \\
\multicolumn{1}{l|}{ Total } &, 474 & 44 & & & \\
\hline
\end{tabular}

a. Dependent Variable: ISR

b. Predictors: (Constant), DER, DPS, ROA

Sumber: Data diolah oleh Penulis

Berdasarkan tabel hasil uji $F$ atau uji ANOVA dapat diketahui bahwa nilai $F$ hitung sebesar 5,617 dengan tingkat signifikansi 0,003, artinya nilai signifikansi lebih kecil dari taraf signifikansi 0,05 atau $0,003<0,005$. Sesuai dengan ketentuan uji $\mathrm{F}$ yang telah diungkapkan pada pembahasan sebelumnya, maka dapat diperoleh kesimpulan bahwa hipotesis $\mathrm{H}_{0}$ ditolak dan hipotesis $\mathrm{H}_{\mathrm{A}}$ diterima, yaitu bahwa secara bersama-sama variabel independen yang terdiri dari dewan pengawas syariah, profitabilitas, leverage berpengaruh signifikan terhadap pengungkapan Islamic Social Reporting (ISR).

\subsection{Uji Hipotesis Parsial (Uji t)}

Uji statistik t pada dasarnya menunjukkan seberapa jauh pengaruh satu variabel penjelas/independen secara individual dalam menerangkan variasi variabel dependen. Hasil uji t ditunjukkan dalam tabel sebagai berikut:

Tabel 4.15.

Hasil Uji Signifikansi Parameter Individual (Uji Statistik t) Coefficients $^{\mathrm{a}}$

\begin{tabular}{|l|r|r|r|r|r|}
\hline \multirow{2}{*}{ Model } & \multicolumn{2}{|c|}{ Unstandardized Coefficients } & $\begin{array}{c}\text { Standardized } \\
\text { Coefficients }\end{array}$ & \multicolumn{1}{c|}{ S } & \multicolumn{1}{l|}{} \\
\cline { 2 - 4 } & \multicolumn{1}{|c|}{ B } & Std. Error & \multicolumn{1}{|c|}{ Beta } & & \\
\hline (Constant) &, 622 &, 020 & & 31,306 &, 000 \\
DPS &, 115 &, 029 &, 529 & 3,989 &, 000 \\
ROA &, 178 &, 377 &, 063 &, 472 &, 639 \\
DER &,- 003 &, 005 &,- 076 &,- 575 &, 569 \\
\hline
\end{tabular}

a. Dependent Variable: ISR

Sumber: Data diolah oleh Penulis

Berdasarkan tabel hasil uji t di atas, untuk variabel dewan pengawas syariah diperoleh nilai $t_{\text {hitung }}$ sebesar 3,989 dan tingkat signifikansi sebesar $0,000<0,05$. Sesuai dengan kriteria uji $\mathrm{t}$ yang telah dibahas sebelumnya, maka dapat diperoleh kesimpulan bahwa hipotesis $\mathrm{H}_{0}$ ditolak dan $\mathrm{H}_{\mathrm{A}}$ diterima, sehingga dapat 
dikatakan bahwa dewan pengawas syariah berpengaruh positif signifikan terhadap pengungkapan Islamic Social Reporting (ISR).

Untuk variabel profitabilitas diperoleh nilai $t_{\text {hitung }}$ sebesar 0,472 dan tingkat signifikansi sebesar $0,639>0,05$. Sesuai dengan kriteria uji t yang telah dibahas sebelumnya, maka dapat diperoleh kesimpulan bahwa hipotesis $\mathrm{H}_{0}$ diterima dan hipotesis $\mathrm{H}_{\mathrm{A}}$ ditolak sehingga dapat dikatakan bahwa profitabilitas berpengaruh tidak signifikan terhadap pengungkapan Islamic Social Reporting (ISR).

Untuk variabel leverage diperoleh $t_{\text {hitung }}$ sebesar $-0,575$ dan tingkat signifikansi sebesar $0,569>0,05$. Sesuai dengan kriteria uji t yang telah dibahas sebelumnya, maka dapat diperoleh kesimpulan bahwa hipotesis $\mathrm{H}_{0}$ diterima dan hipotesis $\mathrm{H}_{\mathrm{A}}$ ditolak sehingga dapat dikatakan bahwa leverage berpengaruh tidak signifikan terhadap pengungkapan Islamic Social Reporting (ISR).

\subsection{Pembahasan Penelitian}

\subsubsection{Pengaruh Dewan Pengawas Syariah Terhadap Pengungkapan Islamic Social Reporting (ISR)}

Hipotesis pertama $\left(\mathrm{H}_{1}\right)$ yang telah dirumuskan dalam penelitian ini bahwa dewan pengawas syariah berpengaruh positif signifikan terhadap pengungkapan Islamic Social Reporting (ISR). Hasil pengujian statistik secara parsial menunjukkan bahwa dewan pengawas syariah berpengaruh positif signifikan terhadap pengungkapan Islamic Social Reporting (ISR). Dengan kata lain, semakin banyak jumlah dewan pengawas syariah maka akan membuat pengawasan terhadap pemenuhan prinsip syariah dalam kegiatan usaha bank umum syariah lebih efektif.

Hasil penelitian ini sejalan dengan penelitian sebelumnya yang dilakukan oleh Ningrum et al. (2013), Ramadhani (2016), Purwanti (2016) dan Mahdalena (2017) yang menyatakan bahwa dewan pengawas syariah berpengaruh terhadap pengungkapan Islamic Social Reporting (ISR). Hasil penelitian ini tidak sejalan dengan hasil penelitian yang dilakukan oleh Khoirudin (2013) dan Maharani dan Yuliyanto (2016) yang menyatakan bahwa dewan pengawas syariah tidak berpengaruh terhadap pengungkapan Islamic Social Reporting (ISR).

Yang menjadi tugas pokok dan perhatian utama dari dewan pengawas syariah adalah dalam hal kepatuhan terhadap prinsip syariah. Salah satu tugas dewan pengawas syariah antara lain mengawasi kegiatan menyalurkan dana zakat, infak, sedekah dan bisa diakui sebagai bentuk Islamic Social Reporting perusahaan. Jadi tidak dapat dipungkiri bahwa dewan pengawas syariah dalam jumlah yang cukup banyak dengan beragam perspektif, pengalaman, kompetensi, baik dalam bidang perbankan dan keuangan, serta keahlian dalam hal hukum Islam akan membuat kinerja bank semakin efektif. Semakin baiknya peran dewan pengawas syariah dalam mengawasi segala aktifitas perbankan yang harus dijalankan didasarkan dengan prinsip-prinsip syariah, maka semakin baik pula kinerja dan output yang dihasilkan oleh perbankan syariah.

\subsubsection{Pengaruh Profitabilitas Terhadap Pengungkapan Islamic Social Reporting (ISR)}

Hipotesis kedua $\left(\mathrm{H}_{2}\right)$ yang telah dirumuskan dalam penelitian ini bahwa profitabilitas berpengaruh positif signifikan terhadap pengungkapan Islamic 
Social Reporting (ISR). Namun, hasil pengujian statistik secara parsial menunjukkan bahwa profitabilitas berpengaruh tidak signifikan terhadap pengungkapan Islamic Social Reporting (ISR). Dengan kata lain, perusahaan yang memiliki niat untuk melakukan pengungkapan ISR tidak akan mempertimbangkan apakah perusahaan tersebut untung atau rugi. Pengungkapan akan tetap dilakukan terlepas dari tinggi atau rendahnya profitabilitas yang dimiliki.

Hasil penelitian ini sejalan dengan penelitian sebelumnya yang dilakukan oleh Astuti (2014), Lestari (2015), dan Ramadhani (2016) yang menyatakan bahwa profitabilitas tidak berpengaruh terhadap pengungkapan Islamic Social Reporting (ISR). Hasil penelitian ini tidak sejalan dengan hasil penelitian yang dilakukan oleh Othman et al. (2009), Widiawati dan Raharja (2012), Anggraini dan Wulan (2015), Eksandy dan Hakim (2015), Wulandari (2015), dan Widarto (2017) yang menyatakan bahwa profitabilitas berpengaruh terhadap pengungkapan Islamic Social Reporting (ISR).

Perusahaan memandang pengungkapan Islamic Social Reporting sebagai suatu kebutuhan. Perusahaan menyadari bahwa pengungkapan Islamic Social Reporting sangat penting sebagai wujud transparansi untuk dapat menambah kepercayaan serta nilai perusahaan di mata para pengguna laporan, terutama stakeholder muslim. Perusahaan beranggapan ketika kondisi keuangan mengalami untung maupun rugi, perusahaan akan tetap melakukan dan mengungkapkan Islamic Social Reporting. Hal ini merupakan wujud dari akuntabilitas kepada Allah SWT dan masyarakat serta memenuhi kebutuhan pengguna laporan dalam pengambilan keputusan.

\subsubsection{Pengaruh Leverage Terhadap Pengungkapan Islamic Social Reporting (ISR)}

Hipotesis ketiga $\left(\mathrm{H}_{3}\right)$ yang telah dirumuskan dalam penelitian ini bahwa leverage berpengaruh negatif signifikan terhadap pengungkapan Islamic Social Reporting (ISR). Namun, hasil pengujian statistik secara parsial menunjukkan bahwa leverage berpengaruh tidak signifikan terhadap pengungkapan Islamic Social Reporting (ISR). Dengan kata lain, besar kecilnya hutang tidak lantas memberikan dampak terhadap besar kecilnya pengungkapan kinerja sosial perbankan syariah.

Hasil penelitian ini sejalan dengan hasil penelitian yang dilakukan oleh Lestari (2015) dan Eksandy dan Hakim (2015) yang menyatakan bahwa leverage tidak berpengaruh terhadap pengungkapan Islamic Social Reporting (ISR). Hasil penelitian ini tidak sejalan dengan penelitian sebelumnya yang dilakukan oleh Astuti (2014), Anggraini dan Wulan (2015), dan Ramadhani (2016) yang menyatakan bahwa leverage berpengaruh terhadap pengungkapan Islamic Social Reporting (ISR).

Leverage yang diukur dengan rasio kewajiban terhadap ekuitas pada bank syariah akan berbeda dengan entitas lainnya. Kewajiban pada bank syariah merupakan sumber utama penghasilan laba dengan sistem bagi hasil nisbah keuntungan. Sedangkan pada entitas non syariah, kewajiban merupakan suntikan modal untuk memaksimalkan laba. Hal ini menandakan bahwa pengungkapan tanggung jawab sosial secara syariah pada perbankan syariah 
telah menjadi suatu kewajiban baik dalam kondisi leverage rendah maupun tinggi.

5.

Berdasarkan hasil penelitian yang telah dilakukan tentang pengaruh dewan pengawas syariah, profitabilitas dan leverage terhadap pengungkapan Islamic Social Reporting (ISR) pada Bank Umum Syariah di Indonesia periode 2013 sampai 2016, maka dapat ditarik kesimpulan sebagai berikut:

1. Dari hasil penelitian, dewan pengawas syariah berpengaruh positif signifikan terhadap pengungkapan Islamic Social Reporting (ISR). Semakin banyak jumlah dewan pengawas syariah dapat meningkatkan level pengungkapan. Semakin besar jumlah anggota dewan pengawas syariah, maka kinerja bank yang sesuai dengan prinsip syariah semakin efektif sehingga pengungkapan tanggung jawab sosial secara islami juga meningkat.

2. Dari hasil penelitian, profitabilitas berpengaruh tidak signifikan terhadap pengungkapan Islamic Social Reporting (ISR). Karena dalam pandangan Islam, perusahaan yang memiliki niat untuk melakukan pengungkapan penuh tidak akan mempertimbangkan apakah perusahaan tersebut untung atau rugi. Sehingga dalam penelitian ini pengungkapan Islamic Social Reporting tidak dipengaruhi oleh untung atau ruginya suatu perusahaan.

3. Dari hasil penelitian, leverage berpengaruh tidak signifikan terhadap pengungkapan Islamic Social Reporting (ISR). Bank Umum Syariah dengan tingkat leverage tinggi atau rendah akan tetap melakukan pengungkapan sebagai bentuk pemenuhan kebutuhan informasi bagi pengguna informasi.

Berdasarkan hasil penelitian dan uraian kesimpulan di atas, maka saran yang akan dikemukakan yaitu bagi peneliti selanjutnya, diharapkan dapat menambah sampel penelitiannya seperti Bank Syariah di Malaysia dan Gulf Corporate Council atau industri yang memiliki visi misi berbasis syariah. Juga dapat mengeksplorasi atau mencari faktor lain yang dapat mempengaruhi pengungkapan Islamic Social Reporting (ISR) selain faktor-faktor yang diteliti pada penelitian ini seperti penerbitan surat berharga syariah, kepatuhan syariah, likuiditas, jenis bank, ukuran bank, dewan komisaris dan lain sebagainya. Juga bagi Bank Umum Syariah diharapkan dapat melakukan pengungkapan Islamic Social Reporting (ISR) secara lebih luas dan lebih baik lagi, dikarenakan selain untuk menarik minat investor, dapat menjadi daya tarik pula bagi masyarakat umum untuk lebih loyal terhadap produk-produk yang ditawarkan oleh Bank Syariah 


\section{DAFTAR PUSTAKA}

Anggraini, Anita., dan Mulyaning Wulan. 2015. Faktor Financial-Non Financial dan Tingkat Pengungkapan Islamic Social Reporting (ISR). Batam: Sekolah Tinggi Ekonomi Islam SEBI. Hal 161-184.

Ariftyarini, Arum, Ratna Anggraini ZR, dan Erika Takidah. 2014. Hubungan Antara Ukuran Perusahaan dan Profitabilitas dengan Pengungkapan CSR Pada Perusahaan yang Terdaftar di Daftar Efek Syariah. E-jurnal Fakultas Ekonomi Universitas Negeri Jakarta Vol. XII, No. 2, 2014.

Arikunto, Suharsimi. 2010. Prosedur Penelitian Suatu Pendekatan dan Praktek. Jakarta: Rineka Cipta.

Astuti, Tri Puji. 2014. Faktor - Faktor Yang Mempengaruhi Pengungkapan Islamic Social Reporting (ISR) Pada Bank Syariah Indonesia. Jurnal. Universitas Muhammadiyah Surakarta.

Chariri, Anis. 2011. Analisis Pelaporan Corporate Social Responsibility Perbankan Syariah dalam Perspektif Shariah Enterprise Theory: Studi Kasus Pada Laporan Tahunan Bank Syariah Mandiri dan Bank Muamalat Indonesia.

Cooke, T. E. 1992. The Impact of Size, stock Market Listing and Industry Type on Disclosure in the Annual Reports of Japanese Listed Corporations. Accounting and Business Research. 22, Hal 229-237.

Darrough, Masako No. 1993. Disclosure Policy and Competition: Cournot vs. Bertrand. The Accounting Review. Vol. 63, No. 3, Tahun 1993, Hal 534561.

Effendi, Muh. Arief. 2009. The Power Of Corporate Governance: Teori dan Implementasi. Jakarta: Salemba Empat.

Eksandy, Arry., dan M. Zulman Hakim. Pengaruh Ukuran Perusahaan, Profitabilitas, dan Leverage Terhadap Pengungkapan Islamic Social Reporting (ISR). Seminar Nasional dan The $4^{\text {th }}$ Call for Syariah Paper.

Faozan, Akhmad. 2014. Optimalisasi Peran Dewan Pengawas Syariah Pada Lembaga Keuangan Syariah. Vol. II, No. 1, Januari-Juni 2014.

Farook, S. Z., \& Lanis, R. 2005. Banking on Islam ? Determinants of CSR Disclosure. International Conference on Islamic Economics and Finance.

Fitria, Soraya dan Dwi Hartanti. 2010. Islam dan Tanggung Jawab Sosial: Studi Perbandingan Pengungkapan Berdasarkan Global Reporting Initiative Indeks dan Islamic Social Reporting Indeks. Simposium Nasional Akuntansi 13. Purwokerto.

Ghozali, Imam. 2006. Aplikasi Analisis Multivariate dengan Program SPSS. Semarang: Badan Penerbit Universitas Diponegoro.

Ghozali, Imam. 2013. Aplikasi Analisis Multivariate dengan Program IBM SPSS 21. Semarang: Badan Penertbit Universitas Diponegoro.

Gray, et. al. 1995. Corporate Social and Environmental Reporting: A Review of Literature and a Longitudinal Study of UK Disclosure. Accounting, Auditing, and Accountability Journal. Vol. 8, No. 2, pp 47-76.

Hadi, Nor. 2011. Corporate Social Responsibility. Yogyakarta: Graha Ilmu.

Haniffa, R. 2002. Social Reporting Disclosure: An Islamic Perspective. Indonesian Management Research. Hal 128-146. 
Haniffa, R., dan M. Hudaib. 2007. Exploring the Ethical Identity of Islamic Banks via Communication in Annual Reports. Journal of Business Ethics, 76, 97116.

Harahap, Sofyan Syafri. 1999. Analisis Kritis Atas Laporan Keuangan. Jakarta: PT RajaGrafindo Persada.

Jannah, Awalya Ma'rifatul dan Asrori. 2016. Pengaruh GCG, Size, Jenis Produk dan Kepemilikan Saham Publik Terhadap Pengungkapan ISR. Accounting Analysis Journal. AAJ. Vol. 5, No. 1, Tahun 2016, Hal 1-9.

Kasmir. 2016. Analisis Laporan Keuangan. Jakarta: PT RajaGrafindo Persada.

Khasanah, Zayyinatul, dan Agung Yulianto. 2015. Islamic Corporate Governance dan Pengungkapan Islamic Social Reporting Pada Bank Umum Syariah. Accounting Analysis Journal. AAJ. Vol. 4, No. 4, Tahun 2015, Hal 1-10.

Khoirudin, Amirul. 2013. Corporate Governance dan Pengungkapan Islamic Social Reporting Pada Perbankan Syariah di Indonesia. Accounting Analysis Journal. AAJ. Vol. 2, No. 2, Tahun 2013, Hal 227-232.

Lestari, Santi. 2015. Pengaruh Tingkat Profitabilitas, Likuiditas, Leverage, Ukuran Perusahaan, dan Umur Perusahaan Terhadap Pengungkapan Islamic Social Reporting Pada Perbankan Syariah Indonesia tahun 20102014. Universitas Negeri Semarang.

Lindrianasari. 2010. CEO Dunia, Suatu Bukti Pentingnya Informasi Akuntansi Dalam Isu Pergantian CEO. Yogyakarta: Kanisius. Hal 34.

Maali, Casson, and Napier. 2003. Social Reporting by Islamic Banks. University of Southampton.

Maharani, Amanda Kyka., dan Agung Yulianto. 2016. Faktor-faktor yang Mempengaruhi Tingkat Pengungkapan Islamic Social Reporting Pada Bank Syariah. Accounting Analysis Journal. AAJ. Vol. 5, No. 1, Tahun 2016, Hal 1-8.

Mahdalena. 2017. Pengaruh Komposisi Dewan Komisaris Independen, Ukuran Dewan Pengawas Syariah, Ukuran Komite Audit dan Kepemilikan Institusional Terhadap Pengungkapan Corporate Social Responsibility Berdasarkan Indeks Islamic Social Reporting (ISR) Pada Bank Umum Syariah yang Terdaftar di Bank Indonesia. Riau: Fakultas Ekonomi, Universitas Maritim Raja Ali Haji.

Muhammad. 2005. Manajemen Bank Syariah. Yogyakarta: Unit Penerbit dan Percetakan AMP YKPN.

Muhammad. 2015. Manajemen Dana Bank Syariah. Jakarta: PT RajaGrafindo Persada.

Nazir, Moh. 2011. Metode Penelitian. Jakarta: Ghalia Indonesia

Ningrum, Ratna Aditya dkk. 2013. Pengaruh Kinerja Keuangan, Kepemilikan Institusional dan Ukuran Dewan Pengawas Syariah Terhadap Pengungkapan Islamic Social Reporting (ISR). Accounting Analysis Journal 4. AAJ. Universitas Negeri Semarang.

Novrizal, Muhammad Fajrul., dan Meutia Fitri. 2016. Faktor-Faktor yang Mempengaruhi Pengungkapan Corporate Social Responbility (CSR) Pada Perusahaan yang Terdaftar di Jakarta Islamic Index (JII) tahun 2012-2015 dengan Menggunakan Islamic Social Reporting (ISR) Index sebagai Tolok 
Ukur. Jurnal Ilmiah Mahasiswa Ekonomi Akuntansi (JIMEKA). Vol. 1, No. 2, Tahun 2016, Hal 177-189.

Nugraheni, Peni, dan Deasy Permatasari. 2016. Perusahaan Syariah dan

Pengungkapan Corporate Social Responsibility: Analisis Pengaruh Faktor Internal dan Karakteristik Perusahaan. Jurnal Akuntansi \& Auditing Indonesia. Vol. 20, No. 2, Desember 2016.

Nurhayati, Sri., dan Wasilah. 2015. Akuntansi Syariah di Indonesia. Jakarta: Salemba Empat.

Othman, R, Thani, A.M., \& Ghani, E. K. 2009. Determinants of Islamic Social Reporting Among Top Sharia-Approved Companies in Bursa Malaysia. Research Journal of International Studies, 12, 4-20.

Othman, R., \& Thani, A.M. 2010. Islamic Social Reporting of Listed Companies in Malaysia. International Business \& Economics Research Journal, 12, 135144.

Othman, R., \& Thani, A.M. 2010. Reporting by Listed Companies in Zimbabwe. The International Journal of Accounting, 33, 605-631.

O'Donovan, G. 2002. Extending The Applicability and Predictive Power of Legitimacy Theory. Accounting, Auditing \& Accountability Journal. Vol. 15, No. 3, Hal 344-371.

Rani Widyasari Eko Putri. Pengaruh Profitabilitas Terhadap Pengungkapan Corporate Social Responsibility. Jurnal Ekonomi Universitas Brawijaya. Hal 23.

Purwanti, Ari. 2016. Dewan Pengawas Syariah dan Pengungkapan Aspek Lingkungan, Produk dan Jasa Pada Bank Syariah. Jurnal Akuntansi dan Keuangan Islam. Vol. 4, No. 2, Tahun 2016.

Putri, Tria Karina, dan Etna Nur Afri Yuyetta. 2014. Faktor-faktor yang mempengaruhi Islamic Social Reporting Perusahaan-perusahaan yang Terdaftar Pada Indeks Saham Syariah Indonesia (ISSI) Tahun 2011-2012. Diponegoro Journal Of Accounting. Vol. 3, No. 2, Tahun 2014, Hal 1-9.

Ramadhani, Febry. 2016. Pengaruh Ukuran Perusahaan, Profitabilitas, Leverage dan Ukuran Dewan Pengawas Syariah Terhadap Pengungkapan Islamic Social Reporting JOM Fekon, Vol. 3, No. 1, 2016, Hal 2487-2500.

Riyadi, Selamet. 2016. Banking Assets and Liability Mangement. Jakarta: Lembaga Penerbit Fakultas Ekonomi dan Bisnis, Universitas Indonesia.

Roziana, Erna Agustin, dan Sofie. 2010. Analisis Faktor-Faktor Yang Mempengaruhi Tingkat Pengungkapan Sosial Dalam Laporan Tahunan Bank Konvensional Dan Bank Syariah Di Indonesia. Islamic Finance \& Business Review. Vol. 5, No.1, Tahun 2010, Hal 54-75.

Rusdianto, Faizal. 2014. The Analysis of Illocutionary Act on Audio File Entitled "Jama'ah Australia - Kepentingan Menghidupkan Amal Masjid." Jurnal Dimensi Pendidikan dan Pembelajaran. Vol. 3, No. 2, 2014, Hal 51-63.

Santoso, Arif Lukman, dan Zaki Murtadho Dhiyaul-Haq. 2017. Determinan Pengungkapan Islamic Social Reporting Pada Bank Umum Syariah di Indonesia. Jurnal Dinamika Akuntansi dan Bisnis. Vol. 4, No. 2, 2017, pp 125-142. 
Sari, Henny Retno, dan Yazid Yud Padmono. 2014. Pengaruh Pengungkapan Corporate Social Responsibility (CSR) dan Ukuran Perusahaan Terhadap

Profitabilitas. Jurnal Ilmu \& Riset Akuntansi. Vol. 3, No. 7, 2014.

Sekaran, Uma. 2006. Metodologi Penelitian untuk Bisnis. Jakarta: Salemba Empat.

Sekaran, Uma \& Bougie, Roger. 2010. Research Method for Business A Skill Building Approach (5th Edition). United Kingdom: John Wiley \& Sons Ltd.

Setiawan, Iwan., Haris Faulid Asnawib, dan Hafiez Sofyani. 2016. Apakah Ukuran, Profitabilitas, dan Praktik Manajemen Laba Memengaruhi Tingkat Pelaksanaan dan Pelaporan Islamic Social Reporting Pada Perbankan Syariah Di Indonesia ? Jurnal Dinamika Akuntansi dan Bisnis. Vol. 3, No.

2, Tahun 2016, Hal 65-76.

Sintia. 2016. Analisis Pengungkapan Corporate Social Responsibility (CSR)

Pada Perbankan Syariah Di Indonesia Berdasarkan Indeks Islamic Social

Reporting (ISR). Yogyakarta: Fakultas Ekonomi, Universitas Mercu Buana.

Sugiyono. 2008. Metode Penelitian Administrasi. Bandung: Alfabeta.

Sugiyono. 2013. Metode Penelitian Bisnis. Bandung: Alfabeta.

Sugiyono. 2015. Metode Penelitian Pendidikan Pendekatan Kuantitatif, Kualitatif dan R \& D. Bandung: Alfabeta

Sugiyono. 2017. Metode Penelitian Kuantitatif, Kualitatif, dan R\&D. Bandung: Alfabeta.

Suryani. 2011. Analisis Pengaruh Financing to Deposit Ratio (FDR) Terhadap Profitabilitas Perbankan Syarian di Indonesia. Walisongo, Vol. 19, No. 1, Mei 2011.

Sutedi, Adrian. 2009. Perbankan Syariah: Tinjauan dan Beberapa Segi Hukum. Jakarta: Ghalia Indonesia.

Syamsudin, Primayuta Ceky. 2009. Rasio Dan Prediksi Perubahan Laba Perusahaan Manufaktur Yang Terdaftar Di Bursa Efek Indonesia. Fakultas Ekonomi Universitas Muhammadiyah Surakarta. BENEFIT Jurnal Manajemen Dan Bisnis. Vol. 13, No. 1, Hal 61-69.

Triyuwono, Iwan. 2012. Akuntansi Syariah Perspektif, Metodologi dan Teori. Jakarta: Raja Grafindo Persada.

Untung, Hendrik Budi. 2009. Corporate Social Responsibility. Jakarta: Sinar Grafika.

Widarto. 2017. Pengaruh Profitabilitas, Ukuran Perusahaan, dan Kinerja Lingkungan Terhadap Pengungkapan Islamic Social Reporting (ISR). Surakarta: Fakultas Ekonomi. Universitas Muhammadiyah Surakarta.

Widiawati, Septi dan Surya Raharja. 2012. Analisis Faktor-Faktor yang Mempengaruhi Islamic Social Reporting Perusahaan-perusahaan yang Terdapat Pada Daftar Efek Syariah Tahun 2009-2011. Diponegoro Journal Of Accounting. Vol. 1, No. 2, Tahun 2012, Hal 1-15.

Wirdyaningsih, dkk. 2005. Bank dan Asuransi Islam di Indonesia. Jakarta: Kencana.

Wulandari, Fitri. 2015. Pengaruh Profitabilitas, Ukuran Perusahaan, Kinerja Lingkungan, dan Leverage Terhadap Pengungkapan Islamic Social Reporting. Surakarta: Fakultas Ekonomi dan Bisnis. Universitas Muhammadiyah Surakarta. 


\section{ISSN}

Yuliani, Rahma Dwi. 2016. Corporate dan Pengungkapan Islamic Social Reporting Pada Perbankan Syariah di Indonesia dan Malaysia. Yogyakarta: Fakultas Ekonomi dan Bisnis. Universitas Muhammadiyah Yogyakarta.

Peraturan Bank Indonesia Nomor 11/33/PBI/2009

Peraturan Bank Indonesia Nomor 6/24/PBI/2004

Undang-Undang Nomor 21 Tahun 2008

Undang-Undang Nomor 40 Tahun 2007

http://www.bi.go.id/

www.iaei-pusat.org/ 